\title{
PERBEDAAN KADAR CALPROTECTIN DAN HUMAN BETA DEFENSIN 2 TINJA PADA NEONATUS PREMATUR YANG MENDAPAT ASI, SUSU FORMULA, DAN KOMBINASINYA
}

\author{
Rusdian Niati Ningsih ${ }^{\star 凶}$, Putri Primawardani ${ }^{\star}$, Eko Sulistijono** , Harjoedi Adji Tjahjono**
}

\begin{abstract}
Abstrak
Insiden enterokolitis nekrotikan (EKN) berkisar 1-5\% dari setiap 1000 kelahiran hidup dengan angka kematian mencapai $20-30 \%$. Pemberian nutrisi yang optimal dapat mengurangi masalah saluran cerna. Penelitian ini bertujuan mengetahui kadar calprotectin sebagai protein inflamasi dan human $B$-defensin 2 (hBD-2) tinja sebgai peptida antimikroba pada neonatus prematur yang mengonsumsi ASI, susu formula, maupun ASI dan susu formula. Penelitian ini terdiri dari 39 sampel yang memenuhi kriteria inklusi terbagi ke dalam tiga kelompok yaitu neonatus prematur yang mengonsumsi ASI saja, susu formula saja, serta kombinasi ASI dan susu formula. Kadar calprotectin dan hBD-2 tinja diukur menggunakan metode ELISA. Hasil menunjukkan rerata kadar calprotectin tinja secara signifikan lebih rendah pada kelompok neonatus prematur yang mendapat ASI saja dibandingkan kelompok susu formula saja maupun kombinasi ASI dan susu formula $(p=0,00)$. Rerata kadar $h B D-2$ tinja secara signifikan lebih rendah pada kelompok neonatus prematur yang mendapat ASI saja dibandingkan kelompok susu formula saja maupun kombinasi ASI dan susu formula ( $p=$ 0,00 ). Kesimpulannya, kadar calprotectin dan hBD-2 tinja neonatus prematur yang mengonsumsi ASI lebih rendah dibandingkan kelompok susu formula maupun kombinasi ASI dan susu formula.
\end{abstract}

Kata kunci: calprotectin, human beta defensin 2, neonatus prematur, tinja.

\section{THE DIFFERENCES OF FECAL CALPROTECTIN AND HUMAN ß-DEFENSIN 2 LEVEL IN PRETERM NEONATES WHICH GETS BREAST MILK, FORMULA MILK, AND ITS COMBINATIONS}

\begin{abstract}
The incidence of necrotizing enterocolitis is ranged $1-5 \%$ among 1000 birth rates with a mortality rate reaching 20-30\%. roviding optmal nutrition can reduce gastrointestinal problems. This study was aimed to investigate the differences of fecal calprotectin and hBD-2 level in breast milk vs formula vs breast milkformula feeding infants in preterm neonates. There are 39 preterm neonates according to the inclusion criteria were divided into three groups (breast milk, formula milk, and combination of breast milk-formula feeding group). Fecal calprotectin and hBD-2 level were measured using ELISA method. This study showed that fecal calprotectin level in the breast milk feeding group was significantly lower as compared to formula feeding group and combination of breast milk-formula feeding group $(p=0.00)$. Fecal hBD-2 level in the breast milk feeding group was significantly lower as compared to the formula feeding group and combination of the breast milk-formula feeding group $(p=0.00)$. In conclusion, fecal calprotectin and hBD-2 level in breast milk feeding group were significantly lower as compared to formula or breast milk-formula feeding group.
\end{abstract}

Keywords: calprotectin, fecal, human beta defensin 2, preterm neonates,.

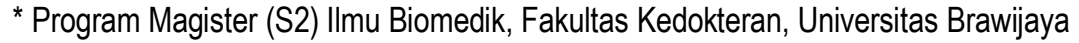

** Departemen Ilmu Kesehatan Anak, Fakultas Kedokteran, Universitas Brawijaya-RSUD Dr. Saiful Anwar, Malang
}

E=mail: rusdian_dr@yahoo.com 


\section{Latar Belakang}

Kelahiran prematur terjadi pada $\pm 10 \%$ kelahiran hidup di seluruh dunia. Insiden sepsis neonatal terjadi pada $10-40 \%$ bayi prematur (usia kehamilan ibu $<37$ minggu), dan bukti klinis menunjukkan bahwa etiologi patogen sepsis neonatal dapat terjadi karena translokasi bakteri dari saluran pencernaan. ${ }^{1}$ Salah satu komponen kunci untuk meningkatkan angka harapan hidup pada neonatus prematur adalah pemberian nutrisi yang optimal. Namun, banyak neonatus prematur memiliki masalah intoleransi diet yang menyebabkan masalah saluran cerna. Strategi yang telah terbukti mengurangi intoleransi makanan pada neonatus prematur adalah penggunaan air susu ibu (ASI). ${ }^{2}$

Salah satu upaya yang dapat dilakukan untuk menurunkan angka morbiditas bahkan mortalitas akibat infeksi saluran cerna yakni deteksi dini bahkan sebelum munculnya gejala klinis. Protein inflamasi dan peptida antimikroba teridentifikasi selama minggu pertama kehidupan, di antaranya adalah calprotectin dan defensin. Calprotectin yang terdeteksi dalam tinja merupakan bagian dari protein inflamasi yang berperan protektif terhadap infeksi.3,4 Defensin yang disekresi oleh epitel (terutama saluran cerna) dan berhubungan dengan reaksi inflamasi adalah human $\beta$ defensin 2. Human ß-defensin 2 (hBD-2) terbukti memiliki efek protektif selama peradangan dan apoptosis, serta mampu menstimulasi perbaikan epitel pada saluran cerna. ${ }^{5}$

Penelitian yang membandingkan pemberian nutrisi enteral dengan kejadian inflamasi saluran cerna masih terbatas. Penelitian ini bertujuan untuk mengetahui kadar calprotectin dan hBD-2 tinja pada neonatus prematur yang mendapat ASI saja, susu formula saja, maupun kombinasi ASI dan susu formula pada usia empat belas hari.

\section{Bahan dan Metode}

\section{Desain Penelitian}

Penelitian ini menggunakan rancangan studi cross-sectional, dilakukan di ruang neonatologi Rumah Sakit Umum Daerah Dr. Saiful Anwar Malang dan Laboratorium Fisiologi, Fakultas Kedokteran Universitas Brawijaya Malang. Penelitian ini telah disetujui oleh Komisi Etik Penelitian Kesehatan Rumah Sakit Umum Daerah Dr. Saiful Anwar Malang dengan nomor surat: 400/244/K.3/302/2019. Dalam penelitian ini menggunakan susu formula dengan nilai kalori $82 \mathrm{kkal} / 100 \mathrm{~mL}$ dan protein $2,1 \mathrm{gram} / 100 \mathrm{~mL}$.

\section{Populasi dan Subjek}

Penelitian ini terdiri dari 39 sampel yang terbagi dalam tiga kelompok yakni neonatus prematur yang mengonsumsi ASI saja, susu formula saja, serta kombinasi ASI dan susu formula. Sampel diambil pada neonatus prematur usia 14 hari. Pengambilan sampel menggunakan spatula.

Kriteria inklusi dari subjek adalah neonatus prematur dengan usia kehamilan kurang atau sama dengan 32 minggu; skor APGAR $>5$ pada menit kelima; tanpa kelainan kongenital, dan riwayat ibu tidak mengalami chorioam-nionitis yang ditandai dengan leukosit lebih dari 20.000/nL dan suhu tubuh lebih dari $38{ }^{\circ} \mathrm{C}$. Kriteria eksklusi dari subjek adalah neonatus prematur dengan kelainan kongenital maupun kelainan bedah saluran cerna; neonatus pre-matur dengan kondisi infeksi.

\section{Persiapan Sampel Tinja}

Sampel diambil dari tinja yang memenuhi persyaratan pengambilan pada neonatus prematur usia 14 hari, antara lain tabung tempat sampel tinja bersih, pengiriman dalam waktu kurang dari 30 menit dan dikirimkan dengan menggunakan wadah khusus yang dapat menjaga suhu stabil. ${ }^{6}$ 
Sejumlah 10 cc buffer ditambahkan untuk setiap $1 \mathrm{mg}$ sampel, kemudian dihomogenkan menggunakan vorteks selama 10 menit dan disentrifus pada suhu $4{ }^{\circ} \mathrm{C}$ dengan kecepatan 3000 rpm selama 20 menit Supernatan yang diperoleh diperiksa menggunakan metode ELISA untuk menentukan kadar calprotectin (E4010Hu, Bioassay Technology Laboratory) dan hBD-2 (E1936Hu, Bioassay Technology Laboratory), pada panjang gelombang $450 \mathrm{~nm}$ untuk menentukan optical density (OD value). Kadar calprotectin dan hBD-2 dikonversi dari nilai absorbansi (OD value) menjadi konsentrasi menggunakan standard curve calprotectin dan hBD-2.

\section{Analisis statistik}

Distribusi data kadar calprotectin dan hBD-2 dianalisis menggunakan uji ShapiroWilk. Uji komparatif untuk mencari perbedaan kadar calprotectin dan hBD-2 pada tiap kelompok menggunakan metode parametrik one-way ANOVA. Semua data dianalisis menggunakan software SPSS versi 21 dengan derajat kepercaayan $\alpha=0,05$.

\section{Hasil}

\section{Karakteristik Sampel}

Penelitian ini terdiri dari 39 sampel yang terbagi dalam tiga kelompok yakni neonatus prematur yang mengonsumsi ASI saja, susu formula saja, serta kombinasi ASI dan susu formula. Karakteristik sampel penelitian yang diamati adalah karakteristik dasar neonatus (jenis kelamin, cara persalinan, usia kehamilan, berat badan lahir, panjang badan lahir, dan lingkar kepala), serta ibu (preeklampsia, eklampsia, riwayat ketuban pecah dini, dan kehamilan gemeli) (Tabel 1).

Tabel 1. Karakteristik sampel penelitian

\begin{tabular}{lccc}
\hline \multicolumn{1}{c}{ Karakteristik } & ASI & $\begin{array}{c}\text { ASI dan } \\
\text { Susu Formula }\end{array}$ & Susu Formula \\
\hline $\begin{array}{l}\text { Jenis kelamin (n) } \\
\text { Laki-laki }\end{array}$ & $6 / 13$ & $4 / 13$ & $4 / 13$ \\
$\quad \begin{array}{c}\text { Perempuan } \\
\text { Usia kehamilan (minggu), }\end{array}$ & $7 / 13$ & $9 / 13$ & $9 / 13$ \\
median (min—maks) & & $30(25-32)$ & \\
$\quad<28$ & $2 / 13$ & $1 / 13$ & - \\
$28-30$ & $4 / 13$ & $6 / 13$ & $5 / 13$ \\
30-32 & $7 / 13$ & $6 / 39$ & $8 / 13$ \\
Berat lahir (gram), rerata (SD) & $1553,8( \pm 430,7)$ & $1459,7( \pm 406,5)$ & $1010( \pm 506,4)$ \\
Panjang lahir, rerata (SD) (cm) & $39,2( \pm 4,6)$ & $39,5( \pm 2,9)$ & $40,9( \pm 4,0)$ \\
Lingkar kepala lahir, rerata (SD) (cm & $28,2( \pm 2,1)$ & $27,8( \pm 1,7)$ & $28,4( \pm 1,8)$ \\
Terapi oksigen (n) & $6 / 13$ & $7 / 13$ & $5 / 13$ \\
Riwayat persalinan (n) & & & \\
$\quad$ Normal & $7 / 13$ & $3 / 13$ & $3 / 13$ \\
$\quad$ Sectio caesarian & $6 / 13$ & $10 / 13$ & $10 / 13$ \\
Riwayat kehamilan ibu (n) & & & \\
$\quad$ Preeklampsia & $3 / 13$ & $4 / 13$ & $6 / 13$ \\
$\quad$ Eklampsia & - & - & $1 / 13$ \\
$\quad$ Ketuban pecah dini & $3 / 13$ & $6 / 13$ & $6 / 13$ \\
$\quad$ Kehamilan gemeli & $2 / 13$ & - & - \\
Klinis (n) & & & \\
$\quad$ Distres napas & $6 / 13$ & $6 / 13$ & $6 / 13$ \\
Muntah & $10 / 13$ & $9 / 13$ & $9 / 13$ \\
Perut membesar & $9 / 13$ & $9 / 13$ & $5 / 13$ \\
Penggunaan antibiotika (n) & $7 / 13$ & $9 / 13$ & $11 / 13$ \\
\hline
\end{tabular}


Tabel 2. Hasil uji komparatif kadar calprotectin dan hBD-2 tinja neonatus prematur

\begin{tabular}{lcc}
\hline \multicolumn{1}{c}{ Variabel Penelitian } & Mean (SD) & p-value \\
\hline Calprotectin $(\mathrm{ng} / \mathrm{mL})$ & & \\
ASI saja & $132,30 \pm 40,31$ & \\
ASI dan susu formula & $244,53 \pm 120,19$ & $0,00^{*}$ \\
Susu formula saja & $386,87 \pm 139,89$ & \\
Human ß-defensin 2 (HBD-2) (ng/mL) & & \\
ASI saja & $204,47 \pm 40,63$ & \\
ASI dan susu formula & $351,66 \pm 38,19$ & $0,00^{*}$ \\
Susu formula saja & $375,73 \pm 69,13$ & \\
\hline
\end{tabular}

Setiap karakteristik dilakukan analisis menggunakan Chi square didapatkan nilai $p=0,84$ yang berarti tidak didapatkan perbedaan signifikan antara masing-masing kelompok.

Median usia kehamilan neonatus yang menjadi sampel penelitian adalah 30 minggu dengan rentang usia kehamilan 25 sampai 32 minggu. Rerata berat badan lahir pada kelompok neonatus yang mengonsumsi ASI adalah $1553,8 \pm 430,7$ gram, kelompok bayi yang mengonsumsi ASI dan susu formula adalah $1459,7 \pm 406,5$ gram, serta kelompok bayi yang mengonsumsi susu formula yakni $1010 \pm 506,4$ $\operatorname{gram}(p=0,84)$.

\section{Kadar Calprotectin dan Human ß-Defensin 2}

Rerata kadar calprotectin tinja secara signifikan lebih rendah pada kelompok neonatus prematur yang mendapat ASI saja $(132,30 \pm 40,31 \mathrm{ng} / \mathrm{mL})$ dibandingkan kelompok susu formula saja $(386,87 \pm 139,89 \mathrm{ng} / \mathrm{mL})$ maupun kombinasi ASI dan susu formula $(244,53 \pm 120,19 \mathrm{ng} / \mathrm{mL} ; p=0,00)$. Rerata kadar hBD-2 tinja secara signifikan lebih rendah pada kelompok neonatus prematur yang mendapat ASI saja $(204,47 \pm 40,63 \mathrm{ng} / \mathrm{mL})$ dibandingkan kelompok susu formula saja $(375,73 \pm 69,13 \mathrm{ng} / \mathrm{mL})$ maupun kombinasi ASI dan susu formula $(351,66 \pm 38,19 \mathrm{ng} / \mathrm{mL} ; p=$ 0,00) (Tabel 2).

\section{Pembahasan}

Neonatus prematur adalah bayi yang lahir pada usia kehamilan kurang dari 37 minggu.
Dari 184 negara di dunia, prevalensi kelahiran prematur berkisar dari 5-18\% dari seluruh bayi yang lahir. ${ }^{7}$ Indonesia merupakan negara kelima tertinggi di dunia dengan jumlah kelahiran neonatus prematur sekitar 675.700 per tahun. ${ }^{8}$ Neonatus prematur mempunyai risiko yang lebih tinggi mengalami gangguan perkembangan otak, gangguan pada jantung, sistem pernapasan, gastrointestinal, serta kekebalan tubuh. Apabila tidak diatasi dengan baik, hal ini dapat berakibat pada kematian.9,10 Maka, dibutuhkan strategi untuk meningkatkan angka harapan hidup dan memperbaiki luaran jangka panjang pada neonatus prematur, salah satunya yakni pemberian nutrisi optimal. ${ }^{11}$ Penelitian ini bertujuan mengetahui kadar calprotectin dan hBD-2 tinja pada neonatus prematur yang mengonsumsi ASI, susu formula, maupun ASI dan susu formula.

Hasil menunjukkan tidak didapatkan perbedaan antara masing-masing kelompok pada seluruh karakteristik dasar sampel penelitian yang diamati baik karak-teristik neonatus (jenis kelamin, cara persalinan, usia kehamilan, berat badan lahir, panjang badan lahir, dan lingkar kepala), maupun ibu (preeklampsia, eklampsia, riwayat ketuban pecah dini, dan kehamilan gemeli).

Pemberian ASI telah dikaitkan dengan penurunan insidensi infeksi pada bayi, termasuk kejadian EKN yang merupakan salah satu kasus darurat pada neonatus prematur.9,10,12,13 Beberapa penelitian menunjukkan bahwa peningkatan calprotectin tinja dapat memprediksi terjadinya EKN.14,15,16 
Calprotectin merupakan heterodimer $36,5 \mathrm{kDa}$ yang terdiri dari satu rantai ringan (MRP8) dan dua rantai berat (MRP14) (8 dan $14 \mathrm{kDa}$ ) dan termasuk $\mathrm{S}-100$ family protein pengikat kalsium. ${ }^{17,18}$ Calprotectin ditemukan dalam sitoplasma granulosit neutrofil, membentuk sekitar $60 \%$ protein sitosol, ${ }^{19}$ diekspresikan pada membran sel monosit dan beberapa sel epitel mukosa, ${ }^{20,21}$ serta dapat berpotensi sebagai tes skrining diagnostik noninvasif untuk peradangan usus. ${ }^{3}$ Calprotectin dapat dengan mudah diukur dalam tinja. Konsentrasinya dalam tinja adalah sekitar enam kali lipat dari plasma. ${ }^{21}$ Calprotectin tinja telah dikaitkan dengan tingkat aktivitas penyakit pada penyakit radang usus pada orang dewasa dan anak-anak.22,23,24,25

Pada penelitian ini didapatkan kadar calprotectin tinja pada kelompok neonatus prematur yang mendapat ASI saja lebih rendah dibandingkan kelompok susu formula saja maupun kombinasi ASI dan susu formula. Hasil ini sesuai dengan penelitian yang dilakukan oleh Rugtveit dan Fagerhol (2002) yang menyatakan kadar calprotectin tinja ditemukan secara signifikan lebih rendah pada bayi yang diberi ASI dibandingkan bayi yang diberi susu formula. ${ }^{26}$ Asgarshirazi et al. (2017) juga melaporkan kadar calprotectin tinja yang lebih tinggi secara signifikan pada bayi bulan pertama dan keenam yang diberi ASI eksklusif dibandingkan dengan mereka yang diberi susu formula atau campuran. ${ }^{27} \mathrm{Hal}$ ini menunjukkan proses inflamasi di usus secara signifikan lebih tinggi terjadi pada kelompok bayi yang mengonsumsi susu formula saja maupun kombinasi. ${ }^{28}$ Namun, hasil yang bertentangan telah dilaporkan oleh beberapa penelitian yaitu kadar calprotectin tinja lebih tinggi pada bayi yang mendapat ASI secara eksklusif, dan beberapa menunjukkan tidak ada perbedaan antara neonatus prematur yang mendapatkan ASI maupun susu formula. 29,30,31 Hal ini disebabkan oleh beberapa faktor yang memengaruhi kadar calprotectin tinja pada neonatus, seperti usia kehamilan, usia bayi, cara persalinan, pemberian antibiotik, mikrobiota usus, dan diet/nutrisi. ${ }^{32}$

Defensin merupakan pertahanan lini pertama dalam melawan infeksi. Defensin yang disekresi pada epitel terutama saluran cerna dan berhubungan dengan reaksi inflamasi yakni human $\beta$-defensin 2 (hBD-2). ${ }^{5}$ Pada penelitian ini didapatkan kadar hBD-2 tinja pada kelompok neonatus prematur yang mendapat ASI saja lebih rendah dibandingkan kelompok susu formula saja maupun kombinasi ASI dan susu formula. Hal ini didukung oleh penelitian yang dilakukan Corebima et al. (2019), dimana kadar hBD-2 tinja secara signifikan lebih rendah pada bayi yang mengonsumsi ASI dibandingkan kelompok yang mengonsumsi kombinasi ASI-susu formula maupun susu formula saja. ${ }^{28}$ hBD-2 terbukti memiliki efek protektif selama peradangan dan apoptosis, serta mampu menstimulasi perbaikan epitel pada saluran pencernaan. ${ }^{5}$ Pang et al. (2014) melaporkan peningkatan hBD-2 pada mukosa kolon yang mengalami inflamasi. ${ }^{33} \mathrm{Hal}$ ini sejalan dengan penelitian oleh Campeotto et al. (2010) yaitu terjadi peningkatan hBD-2 mencerminkan kuatnya respons imun intestinal sehingga bila terdapat inflamasi saluran cerna yang berat akan meningkatkan kadar hBD-2 dalam tinja. ${ }^{34}$ hBD -2 pada ASI dapat membantu mempertahankan imunitas usus bayi. ${ }^{35,36}$

Beberapa keterbatasan dalam penelitian ini yaitu: (1). Sampel yang diperoleh secara conse-cutive sampling dengan keterbatasan waktu penelitian, hal ini dapat mempengaruhi representasi sampel penelitian terhadap populasi umum yang terbatas, (2). Masih didapatkan beberapa faktor perancu yang sulit dihindari dan dapat memengaruhi hasil dalam penelitian ini yakni cara penyimpanan dan transport ASI dari ibu ke petugas perinatologi, penggunaan orogastrik, pemberian antibiotik, dan ruang perawatan di perinatologi (infeksi atau noninfeksi) selama pengamatan dimana memberikan risiko penularan bakteri nosokomial yang berbeda. 
(3). Pengukuran parameter calprotectin dan hBD-2 tinja hanya dilakukan satu kali pengukuran (usia empat belas hari), sehingga tidak dapat diketahui pola perubahan kadar calprotectin dan hBD-2 tinja bayi serta hubungan antara kedua komponen, (4). Penelitian ini tidak mengukur kadar calprotectin dan hBD-2 pada ibu dan mekoneum, sehingga tidak diketahui apakah variabilitas karakteristik selama kehamilan ibu mempengaruhi proses inflamasi ketika hari pertama kelahiran, (5). Mekanisme antiinflamasi juga diperankan oleh sitokin antiinflamasi lainnya yang terinduksi, sehingga dapat memengaruhi kadar calprotectin dan human $\beta$-defensin 2 yang dinilai, (6). Didapatkan perbedaan rata-rata berat badan antara setiap kelompok $>1500$ gram dan $<1500$ gram) dimana berat badan lebih rendah memiliki risiko tinggi terjadinya inflamasi.

\section{Kesimpulan}

Kadar calprotectin dan hBD-2 tinja neonatus prematur yang mengonsumsi ASI lebih rendah dibandingkan kelompok susu formula maupun kombinasi ASI dan susu formula. Hasil menunjukkan bahwa konsumsi ASI memiliki efek protektif terhadap inflamasi pada neonatus prematur.

\section{Daftar Pustaka}

1. Soeorg H, Huik K, Parm U, Ilmoja ML, Metelskaja N, Metsvaht T, Lutsar I. Genetic Relatedness of Coagulase-Negative Staphylococci from Gastrointestinal Tract and Blood of Preterm Neonates with LateOnset Sepsis. Pediatr Infect Dis J. 2013; 32:389-393.

2. Frost B. Maternal Breast Milk Transforming Growth Factor Beta and Feeding Intolerance in Preterm Infants. Journal Pediatr Res. 2014.; 76(4):386-393.

3. Campeotto F, Butel MJ, Kalach N, Derrieux S, Aubert- Jacquin C, Barbot L. High Fecal
Calprotectin Concentrations in Newborn Infants. Arch Dis Child Fetal Neonatal Ed. 2004; 89(4):F353-F355.

4. Vaos G, Kostakis ID, Zavras N, Chatzemichael A. The Role of Calprotectin in Pediatric Disease. Biomed Res Int. 2013; 2013:542363.

5. Otte JM, Werner I, Brand S, Chromik AM, Schmitz F, Kleine M, Schmidt WE. Human Beta Defensin 2 Promotes Intestinal Wound Healing. Journal of Cellular Biochemistry. 2008; 104: 2286-2297.

6. Arisanti D, Wibowo S. Fecal Calprotectin Level of Breast Milk-Formula vs Formula Feeding in Preterm and Low Birth Weight Neonates with Necrotizing Enterocolitis. Journal of Tropical Life Science. 2019; 9 (1):29-33.

7. World Health Organization. Born Too Soon. The Global Action Report on Preterm Birth. 2012.

8. Blencowe $\mathrm{H}$, Cousens $\mathrm{S}$, Oestergaard $\mathrm{M}$, Chou D, Moller AB, Narwal R. National, Regional and Worldwide Estimates of Preterm Birth. Lancet. 2012; 379:2162-72.

9. Neu J, Walker WA. Necrotizing Enterocolitis. The New England Journal of Medicine. 2011; 364: 255-264.

10. Ahle M, Drott P, Andersson RE Epidemiology and Trends of Necrotizing Enterocolitis in Sweden: 1987-2009. Pediatrics. 2013; 132(2):e443 - e451.

11. Franz AR, Pohlandt $F$, Bode $H$, Mihatsch WA, Sander S, Kron M. Intrauterin, Early Neonatal and Post Discharge Growth and Neurodevelopmental Outcome at 5.4 Years in Extremely Preterm Infants after Intensive Nutritional Support. Pediatr. 2009; 123:e101-9.

12. Khader A, Gallagher J, Woods M, Yang WL, Wang $P$, Stylianos S, Prince J. Necrotizing Enterocolitis: An Update on The Benefits of Breast Milk. International Journal of Child Health and Nutrition. 2013; 2:79-84. 
13. Good M, Sodhi CP, Hackam DJ. EvidenceBased Feeding Strategies Before and After The Development of Necrotizing Enterocolitis. Expert Review of Clinical Immunology. 2014; 10(7):875 - 884.

14. Campeotto F, Baldassarre M, Butel MJ. Fecal Calprotectin: Cutoff Values for Identifying Intestinal Distress in Preterm Infants. Journal of Pediatric Gastroenterology and Nutrition. 2009; 48(4):507-510.

15. Aydemir O, Aydemir C, Sarikabadayi YU. Fecal Calprotectin Levels are Increased in Infants with Necrotizing Enterocolitis. Journal of Maternal-Fetal and Neonatal Medicine. 2012; 25(11):2237 - 2241.

16. El Frargy MS, Hassan AM. The Effect of Probiotics Supplementation on Fecal Calprotectin as an Early Marker of Neonatal Enteropathy. Journal of American Science. 2014; 10(8):209 - 213.

17. Kligman D, Hilt DC. The $S 100$ Protein Family. Trends Biochem Sci. 1988; 13 (11):437-443.

18. Bhardwaj RS, Zotz C, Zwadlo-Klarwasser GI. The Calcium-Binding Proteins MRP8 and MRP14 form a Membrane-Associated Heterodimer in a Subset of Monocytes/ Macrophages Present in Acute but Absent in Chronic Inflammatory Lesions. Eur J Immunol. 1992; 22(7):1891-1897.

19. Dale I, Fagerhol MK, Naesgaard I. Purification and Partial Characterization of $A$ Highly Immunogenic Human Leukocyte Protein, The L1 Antigen. Eur J Biochem. 1983; 134(1):1-6.

20. Brandtzaeg P, Dale I, Fagerhol MK. Distribution of a Formalin-Resistant Myelomonocytic Antigen (L1) in Human Tissues. II. Normal and Aberrant Occurrence in Various Epithelia. Am J Clin Pathol. 1987; 87 (6):700-707.

21. Striz I, Trebichavsky I. Calprotectin: A Pleiotropic Molecule in Acute and Chronic Inflammation. Physiol Res. 2004; 53 (3):245-253.

22. Vaos G, Kostakis ID, Zavras N, Chatzemichael A. The Role of Calprotectin in Pedi- atric Disease. Biomed Res Int. 2013; 2013:542363.

23. Tibble JA, Bjarnason I. Non-Invasive Investigation of Inflammatory Bowel Disease. World J Gastroenterol. 2001; 7:460-5.

24. Erbayrak M, Turkay C, Eraslan E, Cetinkaya $\mathrm{H}$, Kasapoglu B, Bektas M. The Role of Fecal Calprotectin in Investigating Inflammatory Bowel Diseases. Clinics. 2009; 64:421-5.

25. Waugh N, Cummins E, Royle P, Kandala N $-B$, Shyangdan D, Arasaradnam R. Fecal Calprotectin Testing for Differentiating Amongst Inflammatory and Noninflammatory Bowel Diseases: Systematic Review and Economic Evaluation. Health Technol Assess. 2013; 17:1- 211.

26. Rugtveit J, Fagerhol MK. Age-Dependent Variations in Fecal Calprotectin Concentrations in Children. J Pediatr Gastroenterol Nutr. 2002; 34(3):323-324.

27. Asgarshirazi M, et al. Comparison of Fecal Calprotectin in Exclusively Breastfed and Formula or Mixed Fed Infants in the First Six Months of Life. Acta Med Iran. 2017; 55 (1):53-58.

28. Corebima BIRV, Rohsiswanto R, Gayatri $P$, Patole S. Fecal Human b-Defensin-2 (hBD -2) Levels and Gut Microbiota Patters in Preterm Neonates with Different Feeding Patterns. Iranian Journal of Microbiology. 2019; 11(2):151-159.

29. Dorosco SM, Mackenzie T, Connor I. Fecal Calprotectin Concentrations are Higher in Exclusively Breastfed Infants Compared to Those who are Mixed-Fed. Breastfeed Med. 2008; 3(2):117-119.

30. Oswari H, Prayitno L, Dwipoerwantoro PG, Firmansyah A, Makrides M, Lawley B. Comparison of Stool Microbiota Compositions, Stool Alpha1-Antitrypsin and Calprotectin Concentrations, and Diarrhoeal Morbidity of Indonesian Infants Fed Breast Milk or Probiotic/Prebiotic Supplemented Formula. J Paediatr Child Health. 2013; 49:1032-9. 
31. Li F, Ma J, Geng S, Wang J, Ren F, Sheng $X$. Comparison of the Different Kinds of Feeding on The Level of Fecal Calprotectin. Early Hum Dev. 2014; 90:471-5.

32. Baldassarre ME, Panza R, Laforgia N. Usefulness of Faecal Markers in Cow's Milk Protein Immunomediated Reactions. Intech Open. 2016; DOI: 10.5772/62544.

33. Pang T, Leach ST, Katz T, Day AS, Ooi CY. Fecal Biomarker of Intestinal Health and Disease in Children. Front Pediatr. 2014; 2(6):1-12.
34. Campeotto F, Baldassarre M, Laforgia N, Viallon V, Kalach N, Amati L, Butel MJ, Dupont C, Kapel N. Fecal Expression of Human Beta Defensin 2 Following Birth. Neonatology. 2010; 98:365-369.

35. He Y, Lawlor NT, Newburg DS. Human Milk Components Modulate Toll like Receptor-Mediated Inflammation. Adv Nutr. 2016; 7:102-11.

36. Klotman ME, Chang TL. Defensin in Innate Antiviral Immunity. Nature Reviews Immunology. 2016; 6:447-456. 